Instrumental Achievements

\title{
A Simple Thin-Layer Spectroelectrochemical Cell for Nonaqueous Solution Systems
}

\author{
Akira Endo, Ikuko Mochida, Kunio Shimizu and Gen P. SATô \\ Department of Chemistry, Faculty of Science and Technology, Sophia University, \\ Kioi-cho, Chiyoda, Tokyo 102, Japan
}

The use of an optically transparent thin-layer electrochemical cell with a gauze or minigrid electrode is one of the most useful methods to characterize the species produced by electron-transfer and/or subsequent chemical reactions. The optically transparent thin-layer electrochemical electrode (OTTLE) originally designed by Heineman ${ }^{1}$ is very simple and useful for aqueous systems, but its use for nonaqueous systems is limited because the epoxy resin used in the cell construction cannot survive long immersion in many organic solvents. For this reason, several types of the cell were designed for nonaqueous systems. ${ }^{2-5}$ Kadish et al. ${ }^{6}$ made a simple thin-layer cell with a platinum gauze electrode. But the way of making the thin-layer chamber ${ }^{7}$ (the thin space where the gauze electrode is sandwiched and the electrolysis takes place) by drawing in a portion of softened cell wall on applying a vacuum requires a delicate glass-blowing skill. Furthermore, the windows of the chamber made in this way cannot be optically flat. Here we describe an OTTLE cell for non-aqueous solutions with optically flat windows, which is based on these authors' design but constructed in a different way.

\section{Cell Construction}

The cross sections of the present thin-layer cell are depicted in Fig. 1. The cell body was made of quartz. The thin-layer was constructed by sandwiching the working electrode of a sheet of doubly folded platinum gauze ( $52 \mathrm{mesh}, 5 \mathrm{~mm} \times 12 \mathrm{~mm}$ ) between a pair of optically flat silica plates. Each plate is the bottom of a cylinder protruding inward from the wall of the cell body. This part was fabricated as follows. First, the gauze electrode was mounted onto the bottom of the cell body; second, a pair of identical cylinders, each having an optically flat silica disk ( $c a .1 \mathrm{~mm}$ thick) at one end, were prepared; and then these cylinders were fused to the cell body in a coaxial position in such a way that the silica disks faced each other sandwiching the gauze electrode. The gap between the disks was about $0.3 \mathrm{~mm}$. With this arrangement, the solution present in the thin-layer chamber can easily be exchanged when the test solution is stirred by passing a stream of argon for $c a .1 \mathrm{~min}$ before the next measurement; the gauze electrode remain

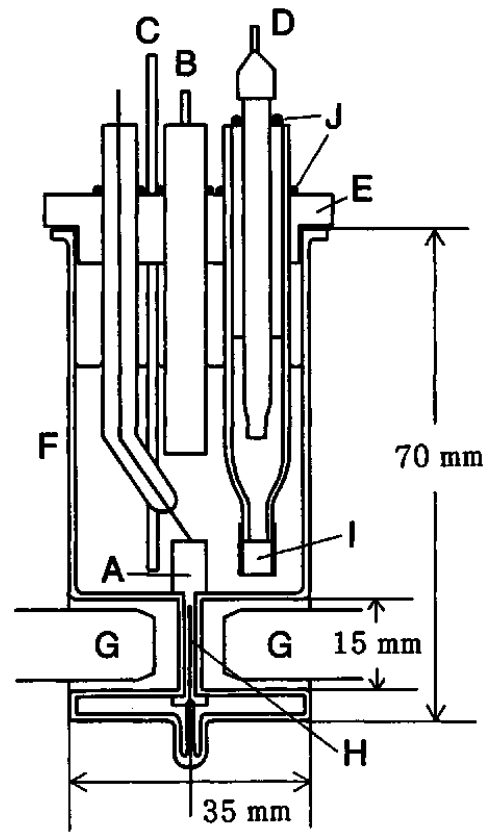

a) Side view

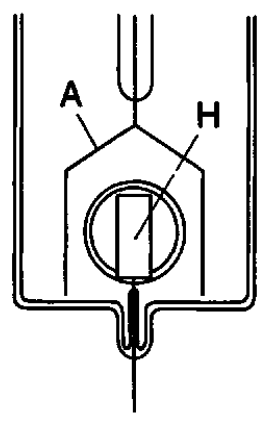

b) Front view

Fig. 1 Cross sections of the OTTLE cell, side view (a) and front view (b). A, counter electrode; B, conventional platinum disk electrode; C, Ar gas inlet (Teflon tube); D, reference electrode $(\mathrm{Ag} \mid \mathrm{AgCl}) ; \mathrm{E}$, Teflon stopper; $\mathrm{F}$, cell body (quartz); G, glass fiber heads; $H$, working electrode (platinum gauze; $5 \mathrm{~mm} \times 12 \mathrm{~mm}$ ); I, Vycor glass tip; J, O-rings.

precisely in position if the cell is subject to ultrasonic cleaning.

An auxiliary electrode made of a sheet of platinum plate surrounded the chamber part. A commercial aqueous $\mathrm{Ag} \mid \mathrm{AgCl}\left(3 \mathrm{~mol} \mathrm{dm}^{-3} \mathrm{NaCl}\right)$ reference electrode was connected to the test solution through a junction filled with the supporting electrolyte solution across a Vycor glass tip. By inserting a conventional stationary disk electrode, the usual cyclic voltammetric experiments can be carried out. The incident and transmitted UVvis light beams are guided to and from the cell by means of a pair of optical fibers inserted into the cavities of the cylinder. The whole cell assembly is firmly fixed in a dark box. 


\section{Experimental}

Electrochemical measurements were carried out by means of a Fuso Polarograph Model 312 with Potential Sweep Unit HECS 321B and Coulometer Model 343. Deoxygenation was carried out by inserting a gas inlet tube of Teflon into the solution and admitting argon gas that was previously passed through the solvent. During measurement, argon was flowed over the solution by pulling up the tip of the gas inlet tube. Spectral measurements were performed by using a Photal MCPD-1000 Spectro Multi Channel Photo Detector with a Photal MC-934 external light source unit. An NEC PC-9801VX personal computer and a Photal MC920 plotter were used for control and data retrieval. Spectra were measured at intervals of $0.5 \mathrm{~s}$ for both the reduction and the oxidation, and the sampling time of each spectrum was $100 \mathrm{~ms}$. All the measurements were carried out at room temperature $\left(c a .20-22^{\circ} \mathrm{C}\right)$.

\section{Results}

The cell performance was evaluated by the following experiments with a solution of $c a .1 \mathrm{mmol} \mathrm{dm}^{-3}$ $\left[\mathrm{Ru}(\mathrm{acac})_{3}\right]^{8}$ in $0.3 \mathrm{~mol} \mathrm{dm}^{-3}$ tetrabutylammonium perchlorate- $\mathrm{CH}_{2} \mathrm{Cl}_{2}$, which exhibits an oxidation and a reduction step, both being Nernstian. Its thin-layer cyclic voltammograms at platinum gauze electrode showed a pair of almost symmetrical peaks corresponding to each process. However, the peak separations between the anodic and cathodic peaks of each couple were $c a .70 \mathrm{mV}$ (scan rate, $2 \mathrm{mV} / \mathrm{s}$ ). For a Nernstian process taking place in an ideal, infinitesimally thin-layer cell, the peak separation should be zero. ${ }^{9}$ The observed peak separation will be attributed mainly to the finite cell thickness and the ohmic effect (an uncompensated resistance of $c a .1 \mathrm{k} \Omega$ could fully account for the peak separation). ${ }^{10}$

The spectral change during the oxidation of $\left[R u(a c a c)_{3}\right]$ by a potential jump from $+0.7 \mathrm{~V}$ to $+1.3 \mathrm{~V}$ is reproduced in Fig. 2. The absorption band at $507 \mathrm{~nm}$ decreased, while the absorption at $688 \mathrm{~nm}$ increased, with an isosbestic point at $528 \mathrm{~nm}$. When the potential returned to the initial value, the spectra went back to the original one. For the reduction process, similar results were obtained. The reproducibility of these measurements was satisfactory.

A typical $\log$-plot ${ }^{11}$ of the absorbance changes at $688 \mathrm{~nm}$ during anodic potential scanning $(1 \mathrm{mV} / \mathrm{s})$ is shown in Fig. 3. Here the ordinate is $\log \left\{\left(A-A_{0}\right) /\right.$ $\left.\left(A_{\infty}-A\right)\right\}$, where $A$ is the absorbance at $E$, and $A_{0}$ and $A_{\infty}$ are absorbances at $+0.7 \mathrm{~V}$ and $+1.3 \mathrm{~V}$, respectively. This plot gave a straight line with a reciprocal slope of $59.9 \mathrm{mV}$ in good agreement with the theoretical value for a one-electron Nernstian process.

The thin-layer chronocoulometric curve of oxidation of $\left[\mathrm{Ru}(\mathrm{acac})_{3}\right]$ is shown in Fig. 4. On stepping the

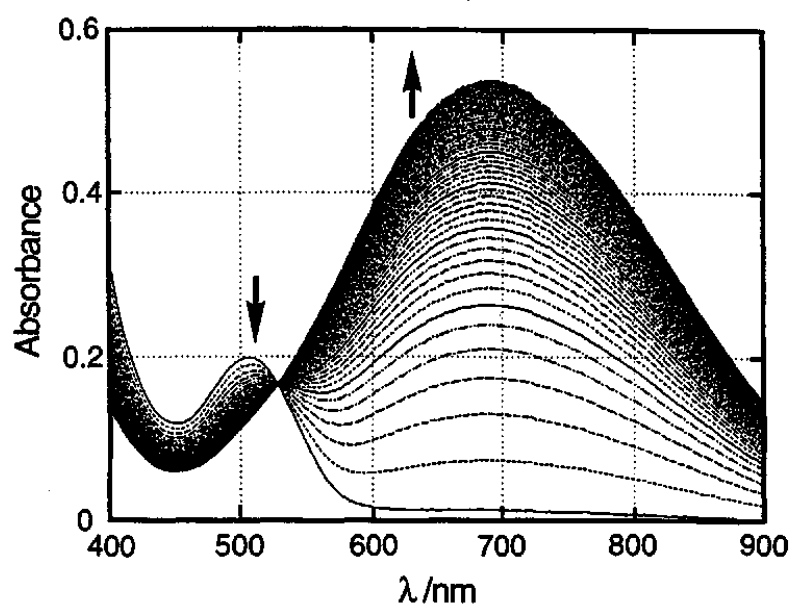

Fig. 2 Visible spectral changes during the oxidation at $+1.3 \mathrm{~V}(0-26.5 \mathrm{~s})$ of $1.0 \mathrm{mmol} \mathrm{dm}^{-3}\left[\mathrm{Ru}(\mathrm{acac})_{3}\right]$ in $0.3 \mathrm{~mol}$ $\mathrm{dm}^{-3} \mathrm{TBAP}-\mathrm{CH}_{2} \mathrm{Cl}_{2}$.

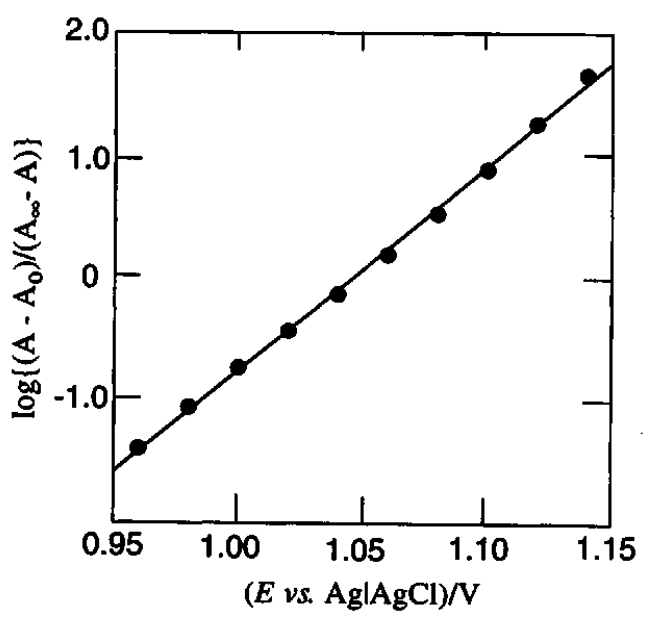

Fig. 3 log-plot of the absorbance changes at $688 \mathrm{~nm}$ of $1.0 \mathrm{mmol} \mathrm{dm}^{-3}\left[\mathrm{Ru}(\mathrm{acac})_{3}\right]$ during the potential scanning in $0.3 \mathrm{~mol} \mathrm{dm}^{-3} \mathrm{TBAP}-\mathrm{CH}_{2} \mathrm{Cl}_{2}$.

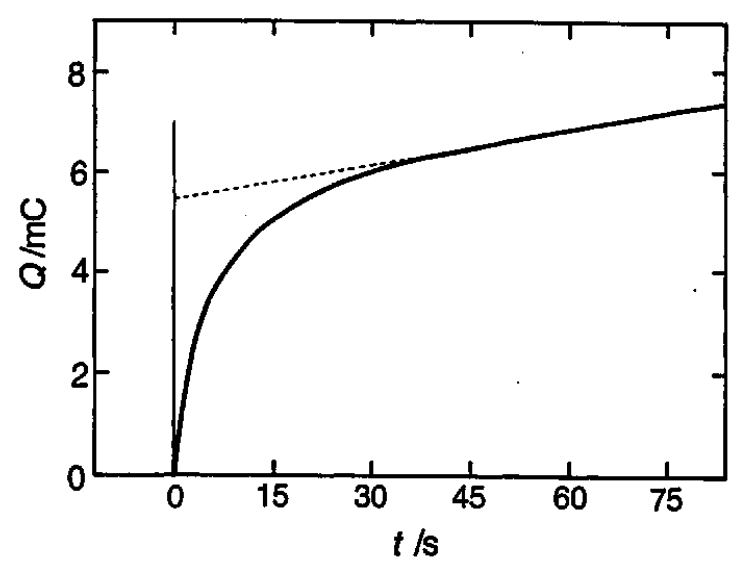

Fig. 4 Thin-layer chronocoulometric curve of oxidation (potential step from $+0.7 \mathrm{~V}$ to $+1.3 \mathrm{~V}$ ) of $1.0 \mathrm{mmol} \mathrm{dm}^{-3}$ $\left[\mathrm{Ru}(\mathrm{acac})_{3}\right]$ in $0.3 \mathrm{~mol} \mathrm{dm}^{-3} \mathrm{TBAP}-\mathrm{CH}_{2} \mathrm{Cl}_{2}$. 
potential to an oxidizing potential, the amount of charge increased rapidly until $c a .30 \mathrm{~s}$, and then increased gradually, indicating that a small amount of the oxidizable species was leaking into the chamber. Extrapolation of the latter, almost linear portion to time 0 , gave a charge of $0.57 \mathrm{mC}$, corresponding to a working volume of the chamber of about $6.0 \mathrm{~mm}^{3}$.

\section{References}

1. W. R. Heineman, B. J. Norris and J. F. Goelz, Anal. Chem., 47, 79 (1975).

2. D. Lexa, J. M. Saveant and J. Zickler, J. Am. Chem. Soc., 99, 2786 (1977).

3. D. A. Scherson, S. Sarangapani and F. L. Urbach, Anal. Chem., 57, 1501 (1985).
4. T. Watanabe and K. Honda, J. Phys. Chem., 86, 2617 (1982).

5. A. J. Bard and L. R. Faulkner, "Electrochemical Methods", John Wiley \& Sons, p. 578, New York, 1980.

6. X. Q. Lin and K. M. Kadish, Anal. Chem., 57, 1498 (1985).

7. Private communication from Dr. X. H. Mu, a member of Dr. Kadish's group.

8. A. Endo, Y. Hoshino, K. Hirakata, Y. Takeuchi, K. Shimizu, Y. Furushima, H. Ikeuchi and G. P. Satô, Bull. Chem. Soc. Jpn., 62, 709 (1988).

9. A. T. Hubbard and F. C. Anson, Anal. Chem., 38, 58 (1966).

10. T. Chen, S. Dong and Y. Xie, J. Electroanal. Chem. Interfacial Electrochem., 379, 239 (1994).

11. D. F. Rohrbach, E. Deutsch, W. R. Heineman and R. F. Pasternack, Inorg. Chem., 16, 2650 (1977).

(Received February 20, 1995)

(Accepted April 17, 1995) 